\title{
Epidemiological evaluation of jaw cysts according to the new WHO classification: a 30 -year retrospective analysis
}

José Rodrigo Barbosa FRANKLIN(a) Eduardo Luis VIEIRA(a) Lívia Natália Sales BRITO(b) (iD) Jurema Freire Lisboa de CASTRO(c) Gustavo Pina GODOY(d)

(a) Universidade Federal de Pernambuco UFPE, School of Dentristry, Recife, PE, Brazil.

(b) Universidade Federal de Pernambuco UFPE, School of Dentristry, Department of Prosthesis and Oral-Facial Surgery, Recife, PE, Brazil.

(c) Universidade Federal de Pernambuco UFPE, School of Dentristry, Department of Clinical and Preventive Dentistry, Recife, PE, Brazil.

(d) Universidade Federal de Pernambuco UFPE, School of Dentristry, Department of Pathology, Recife, PE, Brazil.

Declaration of Interests: The authors certify that they have no commercial or associative interest that represents a conflict of interest in connection with the manuscript.

Corresponding Author:

Gustavo Pina Godoy

E-mail: gruiga@hotmail.com

hitps://doi.org/10.1590/1807-3107bor-2021.vol35.0129

Submitted: September 14, 2020

Accepted for publication: June 2, 2021

Last revision: June 14, 2021
Abstract: The aim of the present study was to analyze the epidemiology of maxillofacial odontogenic and non-odontogenic cysts diagnosed for 30 years in a Brazilian population. A retrospective descriptive cross-sectional study was performed. Biopsy records were obtained from the archives of a Brazilian referral center between 1989 and 2019. Data regarding age, gender, anatomical location, and histopathological diagnosis were collected and categorized. Further, a literature search for similar studies was performed. A total of 6.994 biopsy records were evaluated, but only $367(5.24 \%)$ cases were classified as odontogenic cysts (OC) or non-odontogenic cysts (NOC). Among all cystic lesions, 341 cases $(92.9 \%)$ were OC and 26 cases $(7.1 \%)$ were NOC. These lesions were more common in females $(n=208 / 56.67 \%)$ and located mostly in the mandible ( $\mathrm{n}=195 / 53.1 \%)$. In patients with OC, the radicular cyst was the most frequent $(n=134 / 36.5 \%)$, followed by the dentigerous cyst $(\mathrm{n}=101 / 27.5 \%)$ and the odontogenic keratocyst $(\mathrm{n}=52 / 14.2 \%)$. Patients with NOC had a higher frequency of epidermoid cyst ( $\mathrm{n}=12$ / 3.3\%), oral lymphoepithelial cyst ( $\mathrm{n}=7$ / 1.9\%), and nasopalatine duct cyst $(\mathrm{n}=4 / 1.1 \%)$. The OCs were more prevalent than NOCs, and inflammatory cysts were the most common among all the OCs.

Keywords: Odontogenic Cysts; Epidemiology; Diagnosis; Jaw Cysts.

\section{Introduction}

Cystic lesions are most commonly found in the jaw than in any other bone, and are a frequent cause of swelling in the jaw region. ${ }^{1}$ These lesions can have similar clinical, radiographic, and even histopathological characteristics, and their correct diagnosis is essential because some of these pathologies are susceptible to recurrence and aggressive behavior., ${ }^{1,2}$

Cystic lesions have been classified over the years in different ways, based on tissue origin, radiographic characteristics, or clinical behavior. ${ }^{3}$ Odontogenic cysts $(\mathrm{OC})$ are bone-destructive lesions that originate from epithelial and mesenchymal remnants of dental embryogenesis such as the epithelial rests of Malassez, rests of Serres, and the dental follicle. This characteristic may favor the jaw bones to be a frequent place for the development of these lesions. ${ }^{2,4}$ On the other hand, non-odontogenic 
cysts (NOC) can be considered as a diverse group of lesions that develop from non-odontogenic epithelium, whose possible etiopathogenesis has been discussed over the years. ${ }^{4,5,6}$

According to the most recent classification proposed by the World Health Organization (WHO), cystic lesions are categorized into OC of inflammatory origin (radicular cyst (RC) and inflammatory collateral cyst), developmental OC, and NOC (dentigerous cyst (DC), odontogenic keratocyst $(\mathrm{OKC})$, lateral periodontal cyst, botryoid odontogenic cyst, gingival cyst, glandular odontogenic cyst, calcifying odontogenic cyst (COC), orthokeratinized odontogenic cyst, and nasopalatine duct cyst). ${ }^{7}$

Since 1966, when the first histological definition and classification of odontogenic cysts and tumors was established, these lesions have evolved continuously, and their classifications have been modified to provide safer parameters to support their diagnosis. ${ }^{8}$ The greatest changes in the most recent WHO classification are the replacement of the keratocystic odontogenic tumor (KCOT) and the calcifying cystic odontogenic tumor (CCOT) by the OKC and COC, respectively. ${ }^{8,9}$

The WHO classification did not include dermoid, epidermoid, and oral lymphoepithelial cyst (OLC). However, they are considered NOCs of the maxillofacial region by most authors. ${ }^{6,10,11}$ Similarly, residual cysts were not considered as distinct lesion in this new classification. Residual cysts differ from RCs by demonstrating different biochemical properties due to the lack of communication with the infected root canal system, despite sharing similar histopathological characteristics. ${ }^{12,13,14}$

In this context, epidemiological studies are a reliable source of reference for health professionals to assess and/or manage their patients with greater precision. ${ }^{2,3}$ Demographic and clinical studies in different populations have shown conflicting results and NOCs are somewhat rare lesions. ${ }^{6}$ Thus, this study aimed to describe the frequencies of OC and NOC in the oral and maxillofacial region histopathologically diagnosed over 30 years in a Brazilian population, according to the most recent classification proposed by the WHO.

\section{Methodology}

The study was approved by the Ethics Committee of the Federal University of Pernambuco (approval protocol 02680318.0.0000.5208) and is in accordance with the guidelines of the Declaration of Helsinki. This was a cross-sectional descriptive retrospective study of OC and NOC, whose records from the last 30 years were obtained from the archives of a referral center for oral diagnosis in Brazil. These lesions were evaluated at the Oral Pathology Service of the Federal University of Pernambuco.

OC and NOC were evaluated according to gender, age, and anatomical location, based on the adapted methodology proposed by da Silva et al. ${ }^{15}$.

All hematoxylin-eosin-stained slides of cases previously diagnosed as OC or NOC were re-evaluated by an oral pathologist according to the latest WHO histopathological classification. For further categorization, the residual cyst was considered an inflammatory $\mathrm{OC}^{9}$ because it represents an $\mathrm{RC}$ that remains in the jaw bone after extraction of the affected tooth due to inadequate alveolar curettage.,16 Since the oral, dermoid, and OLC were not included in the new classification, they were categorized according to previous literature. ${ }^{11,15}$ Cases with missing information in the medical records or specimens with insufficient biological material were excluded because of impossible diagnosis.

An extensive literature search was performed to assess studies that evaluated the prevalence of OCs and/or NOCs in Brazilian populations. Observational studies written in English in Brazilian populations were included. Exclusion criteria were studies investigating the prevalence of OC and/or NOCs in specific age groups, studies that did not report histopathological confirmation of the diagnosis, studies published in another language than English, and full text not available. All electronic search strategies were used in the PubMed database using the MeSH terms "odontogenic cysts", "nonodontogenic cysts", "maxilla", "mandible", and "prevalence". All searches were conducted on November 31, 2020. Sex, age, anatomical location, and histopathological diagnosis were collected from all included studies. 
The data were analyzed by descriptive statistics, using the IBMSPSS Statistics 20.0 program (IBMSPSS Inc, Armonk, USA).

\section{Results}

A total of 6,994 oral and maxillofacial lesions were diagnosed during the study period. Of those, 545 (7.79\%) were diagnosed as OC and NOC. However, due to the lack of clinical data or insufficient biological material for histopathological re-evaluation, only 367 lesions (5.24\%) were included in the research, being 341 (92.9\%) classified as OC and $26(7.1 \%)$ as NOC (Table 1). According to the WHO classification, residual cysts $(n=19)$ were included in the radicular cyst category due to their similarities.

Table 2 shows the distribution of OC and NOC according to age and gender. As intraosseous lesions, the inflammatory OCs were located in the maxilla or mandible. On the other hand, developmental OC and NOC have varied anatomical distribution and were categorized in extraosseous (Table 3), and included oral lymphoepithelial cyst in tongue $(n=7)$, dermoid cyst in jaw $(n=2)$ and in the skin of the frontal region $(n=1)$, and epidermoid cyst in jaw $(n=2)$, in the skin of the frontal region $(n=3)$, mouth floor $(n=4)$, and jugal mucosa $(n=2)$.

Details about the studies from the literature review are available in Table 4.

\section{Discussion}

Accurate data from epidemiological studies are essential for the elaboration of disease treatment and prevention strategies for a certain population. Such data also allow actions to reduce the impairment caused by aggressive and/or recurrent lesions.,17

The determination of risk groups can help direct health and disease prevention actions with greater precision. ${ }^{18}$ Several studies show a higher prevalence of OC and NOC in men, ${ }^{2,3,17,19}$ but we found a higher frequency of women $(\mathrm{n}=208$ / $56.67 \%)$, similar to previous surveys,${ }^{4,15,20}$ which can be attributed to the cultural factor of women usually consulting health professionals more often than men. ${ }^{21}$

Table 1. Frequency distribution of odontogenic and non-odontogenic cysts.

\begin{tabular}{|c|c|c|c|}
\hline Cyst & Frequency (n) & Percentage in group (\%) & Percentage in total (\%) \\
\hline \multicolumn{4}{|l|}{ Inflammatory odontogenic cysts } \\
\hline Radicular cyst & 134 & 36.5 & 1.9 \\
\hline Inflammatory collateral cyst & 32 & 8.7 & 0.4 \\
\hline \multicolumn{4}{|l|}{ Developmental odontogenic cysts } \\
\hline Dentigerous cyst & 101 & 27.5 & 1.4 \\
\hline Odontogenic keratocyst & 52 & 14.2 & 0.7 \\
\hline Gingival cyst & 1 & 0.3 & 0.01 \\
\hline Glandular odontogenic cyst & 7 & 1.9 & 0.10 \\
\hline Calcifying odontogenic cyst & 12 & 3.3 & 0.17 \\
\hline Orthokeratinized odontogenic cyst & 2 & 0.5 & 0.02 \\
\hline \multicolumn{4}{|l|}{ Developmental non-odontogenic cysts } \\
\hline Nasopalatine duct cyst & 4 & 1.1 & 0.05 \\
\hline Oral lymphoepithelial cyst & 7 & 1.9 & 0.10 \\
\hline Dermoid cyst & 3 & 0.8 & 0.04 \\
\hline Epidermoid cyst & 12 & 3.3 & 0.17 \\
\hline Total in group & 367 & 100 & - \\
\hline Total in geral & 6994 & - & 5.2 \\
\hline
\end{tabular}


Epidemiological evaluation of jaw cysts according to the new WHO classification: a 30-year retrospective analysis

Table 2. Distribution of odontogenic and non-odontogenic cysts according to age and gender.

\begin{tabular}{|c|c|c|c|c|}
\hline \multirow{2}{*}{ Cyst } & \multirow{2}{*}{$\begin{array}{c}\text { Age } \\
\text { Mean }( \pm S D)\end{array}$} & \multicolumn{2}{|c|}{ Gender } & \multirow{2}{*}{$\begin{array}{c}\text { Total } \\
\mathrm{n}\end{array}$} \\
\hline & & Female & Male & \\
\hline \multicolumn{5}{|l|}{ Inflammatory odontogenic cysts } \\
\hline Radicular cyst & $36.50( \pm 17.28)$ & 63 & 71 & 134 \\
\hline Inflammatory collateral cyst & $26.03( \pm 4.51)$ & 26 & 6 & 32 \\
\hline \multicolumn{5}{|l|}{ Developmental odontogenic cysts } \\
\hline Dentigerous cyst & $23.77( \pm 11.91)$ & 66 & 35 & 101 \\
\hline Odontogenic keratocyst & $33.60( \pm 20.01)$ & 28 & 24 & 52 \\
\hline Gingival cyst & $26.00(-)$ & 1 & - & 1 \\
\hline Glandular odontogenic cyst & $55.43( \pm 20.69)$ & 3 & 4 & 7 \\
\hline Calcifying odontogenic cyst & $25.17( \pm 21.54)$ & 6 & 6 & 12 \\
\hline Orthokeratinized odontogenic cyst & $47.00( \pm 4.24)$ & 0 & 2 & 2 \\
\hline \multicolumn{5}{|l|}{ Developmental non-odontogenic cysts } \\
\hline Nasopalatine duct cyst & $47.00( \pm 17.32)$ & 3 & 1 & 4 \\
\hline Oral lymphoepithelial cyst & $45.57( \pm 6.40)$ & 7 & 0 & 7 \\
\hline Dermoid cyst & $34.00( \pm 19.47)$ & 1 & 2 & 3 \\
\hline Epidermoid cyst & $32.17( \pm 20.13)$ & 4 & 8 & 12 \\
\hline Total (\%) & 31.81 ( \pm 17.09$)$ & $208(56.67)$ & 159 (43.32) & 367 \\
\hline
\end{tabular}

Table 3. Distribution of odontogenic and non-odontogenic cysts according to anatomical site.

\begin{tabular}{lccc}
\hline Cyst & Maxilla & Mandible & Extraosseous \\
\hline Radicular cyst & 91 & 43 & 32 \\
Inflammatory collateral cyst & 0 & 75 & - \\
Dentigerous cyst & 26 & 36 & - \\
Odontogenic keratocyst & 16 & 1 & - \\
Gingival cyst & - & 2 & - \\
Glandular odontogenic cyst & 5 & 5 & - \\
Calcifying odontogenic cyst & 7 & 1 & - \\
Orthokeratinized odontogenic cyst & 1 & - & - \\
Nasopalatine duct cyst & 4 & - & 7 \\
Oral lymphoepithelial cyst & - & & 3 \\
Dermoid cyst & - & $195(53.13)$ & $22(5.99)$ \\
Epidermoid cyst & - & & - \\
Total (\%) & $150(40.87)$ & & - \\
\hline
\end{tabular}

Regarding age, in general, the majority of our sample was in their thirties, similar to some previous evaluations. ${ }^{2,4,6,11,19,20,22}$ However, other studies have reported different age groups being more affected, with an average age between 43 and 45 years. ${ }^{10,17}$ Few surveys have categorized these cysts according to age group, but da Silva et al. ${ }^{15}$ highlights the importance of this analysis, which facilitates the understanding of the characteristics inherent to each age group. As humans present physiological and behavioral changes in each stage of life, the treatment and prognosis of diseases 
Table 4. Distribution of odontogenic and non-odontogenic cysts from the present study and selected references in Brazilian populations.

\begin{tabular}{|c|c|c|c|c|c|c|}
\hline \multirow{2}{*}{ Study (year) } & \multicolumn{2}{|c|}{ Gender (\%) } & \multirow{2}{*}{$\begin{array}{c}\text { Age } \\
\text { (prevalence) }\end{array}$} & \multirow{2}{*}{$\begin{array}{l}\text { Localization } \\
(\%)\end{array}$} & \multirow{2}{*}{$\begin{array}{l}\text { Prevalence of odontogenic } \\
\text { cyst }(\mathrm{n} / \%)\end{array}$} & \multirow{2}{*}{$\begin{array}{c}\text { Prevalence of } \\
\text { non-odontogenic cyst }(\mathrm{n} / \%)\end{array}$} \\
\hline & $\mathrm{F}$ & M & & & & \\
\hline Present study (2020) & $(43.33)$ & $(56.67)$ & $\begin{array}{l}\text { 3rd decade } \\
\text { of life }\end{array}$ & $\begin{array}{l}\text { Mandible } \\
\text { (54.2) }\end{array}$ & Radicular cyst (134/36.5) & Epidermoid cyst (12/3.3) \\
\hline $\begin{array}{l}\text { Uchoa-Vasconcelos et al. } \\
(2014)^{6}\end{array}$ & $(50.70)$ & $(49.3)$ & $\begin{array}{c}\text { 3rd decade } \\
\text { of life }\end{array}$ & $\begin{array}{l}\text { Maxilla } \\
(42.2 \%)\end{array}$ & Not avaliable & $\begin{array}{c}\text { Nasopalatine duct cyst } \\
(31 / 43.66)\end{array}$ \\
\hline Nonaka et al. $(2011)^{11}$ & $(65.5)$ & (34.5) & $\begin{array}{l}\text { 3rd decade } \\
\text { of life }\end{array}$ & $\begin{array}{l}\text { Floor of the } \\
\text { mouth }(80)\end{array}$ & Not avaliable & $\begin{array}{l}\text { Nasopalatine duct cysts } \\
(32.8)\end{array}$ \\
\hline Souza et al. $(2010)^{20}$ & (55.9) & $(44.1)$ & $\begin{array}{l}\text { 3rd decade } \\
\text { of life }\end{array}$ & $\begin{array}{l}\text { Maxilla } \\
(53.8)\end{array}$ & Radicular cysts (61.4) & Not avaliable \\
\hline Avelar et al. (2009) ${ }^{24}$ & $(42.4)$ & $(57.6)$ & $\begin{array}{c}\text { 2nd decade } \\
\text { of life }\end{array}$ & $\begin{array}{l}\text { Mandible } \\
\text { (56) }\end{array}$ & Radicular cyst (265/52.2) & Not avaliable \\
\hline Gross-mann et al. $(2007)^{4}$ & $(49.26)$ & $(48.78)$ & $\begin{array}{l}\text { 3rd decade } \\
\text { of life }\end{array}$ & $\begin{array}{l}\text { Maxilla } \\
(50.9)\end{array}$ & Radicular cyst (1.772/61) & $\begin{array}{c}\text { Nasopalatine duct cyst } \\
(64 / 2.2)\end{array}$ \\
\hline
\end{tabular}

must consider the age factor. According to the literature review, these lesions have the highest prevalence in people in the third decade of life in Brazilian populations.

The location of a lesion is a relevant diagnostic factor for complex cases that require a differential diagnosis. ${ }^{23}$ In the population of this study, the mandible was a slightly more frequent location ( $n=195 / 53.13 \%$ ) for OC and NOC, in agreement with several previous evaluations. ${ }^{3,17,22,24}$

Several authors cited the $\mathrm{RC}$ as the most frequent group of inflammatory odontogenic cystic lesions, including in Brazilian populations, ${ }^{3,4,9,10,17,20,24}$ corroborating the results of this study, where $36.5 \%$ were RC lesions. The high incidence of RCs can be related to the poor oral health conditions of the general population and the lack of public incentives to prevent oral infections, ${ }^{3,17}$ leading to the development of dental caries, which can progress to pulp necrosis and the formation of inflammatory periapical lesions, such as RCs.

The DC and OKC also had relatively high frequencies $(n=101 / 27.5 \%$ and $(n=52 / 14.2 \%$, respectively) confirming previous results. $3,17,19,22,25$ However, according to Mohajerani et al., ${ }^{23}$ the most prevalent OCs were OKCs $(\mathrm{n}=50 / 32.1 \%)$ followed by DCs $(n=40 / 25.6 \%)$ and RCs $(n=27 / 19.9 \%)$. Despite the known high incidence of RCs, their prevalence could be higher if periapical lesions were sent for analysis more often by dentists.
The OKC is an aggressive lesion with marked tendency for recurrence. When classified as a tumor, it was the most common one. ${ }^{17}$ However, when categorized as a cystic lesion, the OKC was the third most common lesion in the evaluated population. The OKC was more common in males and the mandible was the most affected location. ${ }^{7}$ The criteria used by the $\mathrm{WHO}$ to change the classification of OKC were its aggressive behavior, high recurrence rate, and mutations of the PTCH gene. The molecular/genetic changes that occur in some OKCs can influence their biological behavior; however, such changes do not yet characterize OKCs as lesions of neoplastic origin, but rather cystic. ${ }^{8}$

Although some researchers reported that the most prevalent NOC cyst was the NDC, $6,10,11$ this study found the epidermoid cyst $(n=12 / 3.3 \%)$ as the most prevalent NOC lesion followed by the OLC $(n=7 / 1.9 \%)$. Because the pathogenesis of these lesions remains unknown, inferences about this prevalence cannot be drawn from the present study.

Third molars erupt at around 20 years of age, ${ }^{26}$ and the development of $\mathrm{OC}$ can occur during the process. According to Godoy et al. ${ }^{27}$, the DC is a developmental follicular cyst that adheres to the cementoenamel junction region of an unerupted tooth. For these authors, the squamous metaplasia of the reduced enamel epithelium adheres to the stratified epithelium, where this epithelium will be predominantly continuous and thin. In the study 
by Shin et al., ${ }^{28}$ a high prevalence of DCs was found in young adults during the period of third molar eruption, similar to our findings.

In the present study, all cases of inflammatory collateral cyst occurred in the mandible. As known, these cysts are associated with a history of recurrent or persistent pericoronitis in lower third molars. The inflammation due to the accumulation of food in the area, with subsequent proliferation of bacteria can lead to the development of the cyst. ${ }^{2}$ Similar results were reported by others studies..$^{15,20}$

The clinical and radiographic analysis are fundamental tools for a differential diagnosis. ${ }^{29}$ However, the high sample loss in this research indicates the negligence of health professionals with the management of clinical records. Thus, the careful surgical manipulation of the lesions, appropriate fixation of the sample, and documentation of the largest possible number of clinical and radiographic data are highly recommended for minimizing losses and obtaining conclusive reports.

\section{Conclusion}

The new WHO classification of cystic lesions did not impact the diagnosis or the epidemiological profile of these lesions in a Brazilian population sample. The results with the new classification were similar to several previous studies in Brazilians populations. The OCs were more prevalent than NOCs and inflammatory cysts are the most common OCs.

\section{Acknowledgment}

The authors would like to thank the National Council for Scientific and Tecnological Development (\#424284/2018-9). GP Godoy is research fellow of CNPq, Brazil.

\section{References}

1. Tekkesin MS, Olgac V, Aksakalli N, Alatli C. Odontogenic and nonodontogenic cysts in Istanbul: analysis of 5088 cases. Head Neck. 2012 Jun;34(6):852-5. https://doi.org/10.1002/hed.21820

2. Lo Muzio L, Mascitti M, Santarelli A, Rubini C, Bambini F, Procaccini M, et al. Cystic lesions of the jaws: a retrospective clinicopathologic study of 2030 cases. Oral Surg Oral Med Oral Pathol Oral Radiol. 2017 Aug;124(2):128-38. https://doi.org/10.1016/i.0000.2017.04.006

3. Jaafari-Ashkavandi Z, Akbari B. Clinicopathologic study of intra- osseous lesions of the jaws in Southern Iranian population. J Dent (Shiraz). 2017 Dec;18(4):259-64.

4. Grossmann SM, Machado VC, Xavier GM, Moura MD, Gomez RS, Aguiar MC, et al. Demographic profile of odontogenic and selected nonodontogenic cysts in a Brazilian population. Oral Surg Oral Med Oral Pathol Oral Radiol Endod. 2007 Dec;104(6):e35-41. https://doi.org/10.1016/i.tripleo.2007.05.028

5. Daley TD, Wysocki GP, Pringle GA. Relative incidence of odontogenic tumors and oral and jaw cysts in a Canadian population. Oral Surg Oral Med Oral Pathol. 1994 Mar;77(3):276-80. https://doi.org/10.1016/0030-4220(94)90299-2

6. Uchoa-Vasconcelos AC, Filizola-de Oliveira DJ, Roman-Martelli SJ, Etges A, Neutzling-Gomes AP, Chaves-Tarquínio SB. Demographic profile of oral nonodontogenic cysts in a Brazilian population. Med Oral Patol Oral Cir Bucal. 2014 Jul;19(4):e308-12. https://doi.org/10.4317/medoral.19335

7. El-Naggar AK, Chan JK, Grandis JR, Takata T, Sootweg P. World Health Organization classification of head and neck tumours. 4th ed. Lyon: IARC; 2017.

8. Bianco BC, Sperandio FF, Hanemann JA, Pereira AA. New WHO odontogenic tumor classification: impact on prevalence in a population. J Appl Oral Sci.2019;28: e20190067. https://doi.org/10.1590/1678-7757-2019-0067

9. Tamiolakis P, Thermos G, Tosios KI, Sklavounou-Andrikopoulou A. Demographic and clinical characteristics of 5294 jaw cysts: a retrospective study of 38 years. Head Neck Pathol. 2019 Dec;13(4):587-96. https://doi.org/10.1007/s12105-019-01011-7

10. Jones AV, Franklin CD. An analysis of oral and maxillofacial pathology found in adults over a 30 -year period. J Oral Pathol Med. 2006 Aug;35(7):392-401. https://doi.org/10.1111/j.1600-0714.2006.00451.x

11. Nonaka CF, Henriques AC, Matos FR, Souza LB, Pinto LP. Nonodontogenic cysts of the oral and maxillofacial region: demographic profile in a Brazilian population over a 40-year period. Eur Arch Otorhinolaryngol. 2011 Jun;268(6):917-22. https://doi.org/10.1007/s00405-010-1458-x 
12. Muglali M, Komerik N, Bulut E, Yarim GF, Celebi N, Sumer M. Cytokine and chemokine levels in radicular and residual cyst fluids. J Oral Pathol Med. 2008 Mar;37(3):185-9. https://doi.org/10.1111/j.1600-0714.2007.00595.x

13. Nonaka CF, Maia AP, Nascimento GJ, Freitas RA, Souza LB, Galvão HC. Immunoexpression of vascular endothelial growth factor in periapical granulomas, radicular cysts, and residual radicular cysts. Oral Surg Oral Med Oral Pathol Oral Radiol Endod. 2008 Dec;106(6):896-902. https://doi.org/10.1016/j.tripleo.2008.06.028

14. Lin LM, Ricucci D, Lin J, Rosenberg PA. Nonsurgical root canal therapy of large cyst-like inflammatory periapical lesions and inflammatory apical cysts. J Endod. 2009 May;35(5):607-15. https://doi.org/10.1016/i.joen.2009.02.012

15. Silva LP, Gonzaga AK, Severo ML, Barros CCS, Medeiros AMC, Souza LB, et al. Epidemiologic study of odontogenic and non-odontogenic cysts in children and adolescents of a Brazilian population. Med Oral Patol Oral Cir Bucal. 2018;23:e49 e53. https://doi.org/10.4317/medoral.22138..

16. Rajendra Santosh AB. Odontogenic cysts. Dent Clin North Am. 2020 Jan;64(1):105-19. https://doi.org/10.1016/i.cden.2019.08.002

17. Johnson NR, Savage NW, Kazoullis S, Batstone MD. A prospective epidemiological study for odontogenic and non-odontogenic lesions of the maxilla and mandible in Queensland. Oral Surg Oral Med Oral Pathol Oral Radiol. 2013 Apr;115(4):515-22. https://doi.org/10.1016/i.0000.2013.01.016

18. Pereira LP, Nery AA. Planning, management and actions of men's health in the family health strategy. Esc Anna Nery. 2014;18(4):63543. https://doi.org/10.5935/1414-8145.20140090

19. Demirkol M, Ege B, Yanik S, Aras MH, Ay S. Clinicopathological study of jaw cysts in southeast region of Turkey. Eur J Dent. 2014 Jan;8(1):107-11. https://doi.org/10.4103/1305-7456.126260

20. Souza LB, Gordón-Núñez MA, Nonaka CF, Medeiros MC, Torres TF, Emiliano GB. Odontogenic cysts: demographic profile in a Brazilian population over a 38-year period. Med Oral Patol Oral Cir Bucal. 2010 Jul;15(4):e583-90. https://doi.org/10.4317/medoral.15.e583

21. Silva PS, Boing AF, Peres KG. Reduction of inequalities in medical visits in Brazil: analysis of the Northeastern and Southeastern regions between 2003 and 2008. Rev Bras Epidemiol. 2015 Jan-Mar;18(1):248-61. https://doi.org/10.1590/1980-5497201500010019

22. Tortorici S, Amodio E, Massenti MF, Buzzanca ML, Burruano F, Vitale F. Prevalence and distribution of odontogenic cysts in Sicily: 1986-2005. J Oral Sci. 2008 Mar;50(1):15-8. https://doi.org/10.2334/josnusd.50.15

23. Mohajerani H, Esmaeelinejad M, Sabour S, Aghdashi F, Dehghani N. Diagnostic Factors of odontogenic cysts in Iranian population: a retrospective study over the past two decades. Iran Red Crescent Med J. 2015 Jun;17(6):e21793. https://doi.org/10.5812/ircmi.21793v2

24. Avelar RL, Antunes AA, Carvalho RW, Bezerra PG, Oliveira Neto PJ, Andrade ES. Odontogenic cysts: a clinicopathological study of 507 cases. J Oral Sci. 2009 Dec;51(4):581-6. https://doi.org/10.2334/josnusd.51.581

25. Jaeger F, Noronha MS, Silva ML, Amaral MB, Grossmann SM, Horta MC, et al. Prevalence profile of odontogenic cysts and tumors on Brazilian sample after the reclassification of odontogenic keratocyst. J Craniomaxillofac Surg. 2017 Feb;45(2):267-70. https://doi.org/10.1016/i.jcms.2016.12.011

26. Moffitt AH. Eruption and function of maxillary third molars after extraction of second molars. Angle Orthod. 1998 Apr;68(2):147-52. https://doi.org/10.1043/0003-3219(1998)068<0147:EAFOMT>2.3.CO;2

27. Godoy GP, Silveira EJ, Lins RD, Souza LB, Freitas RA, Queiroz LM. Immunohistochemical profile of integrins in enlarged dental follicles and dentigerous cysts. Oral Surg Oral Med Oral Pathol Oral Radiol Endod. 2007 Dec;104(6):e29-34. https://doi.org/10.1016/j.tripleo.2007.05.024

28. Shin SM, Choi EJ, Moon SY. Prevalence of pathologies related to impacted mandibular third molars. Springerplus. 2016 Jun;5(1):915. https://doi.org/10.1186/s40064-016-2640-4

29. Rioux-Forker D, Deziel AC, Williams LS, Muzaffar AR. Odontogenic cysts and tumors. Ann Plast Surg. 2019 Apr;82(4):469-77. https://doi.org/10.1097/SAP.0000000000001738 